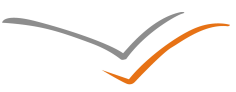

VERSITA

\title{
Interpretation of Geoheritage for Geotourism - a Comparison of Chinese geoparks and National Parks in the United States
}

Fang Ren', Louis Simonson², Zhixin Pan² / e-mail: fren@slu.edu

${ }^{1}$ Department of Earth and Atmospheric Sciences, Saint Louis University, St. Louis, MO, USA

${ }^{2}$ School of Geography and Planning, Sun Yat-sen University, Guangzhou, China

Ren, F., Simonson, L., \& Pan, Z. (2013). Interpretation of Geoheritage for Geotourism - a Comparison of Chinese geoparks and National Parks in the United States. Czech Journal of Tourism, 2(2), 105-125. DOI: 10.2478/cjot-2013-0006.

\begin{abstract}
This study presents an interpretation system model of geoheritage to facilitate the understanding of geoscience knowledge by the common lay person. Interpretation system construction is crucial to geoparks and is a shared value. The improvement of the effectiveness of geoheritage interpretation is still under exploration. Therefore, the interpretation systems of two global geoparks in China are outlined and compared with the interpretation system in Zion National Park in the United States. From lessons and experiences, this paper suggests utilizing geotourism as a complete contextual communication system, in which a geopark (source) delivers information about its unique cultural and natural values to target tourists (receivers) through tourism activities (channels). The communication effect of geotourism is monitored by feedback from tourists through the post-travel surveys or activities. We expect that this model will provide a better interpretation of geoheritage with a new perspective.
\end{abstract}

\section{Keywords}

Geotourism, Geopark, Geoheritage, Interpretation System, Communication channels

JEL classification: I00, I25, Z00 / Accepted: 7 November 2013 


\section{Introduction}

The concept of a geopark, as outlined in the operational guidelines published by UNESCO, is to serve the three goals of conserving a healthy environment, educating in the earth sciences, and fostering sustainable, local economic development. The ultimate goal of geoparks program is to provide for a better understanding of geological heritage and wise use of the earth (Nowlan, et al., 2004). Geopark plays an important role in the development of geotourism. The interpretation of geoheritage is considered the art of explaining the meaning and significance of geological sites to the tourists that visit. Interpretation system of a geopark is critical for improving the image of the park and for achieving the goals of geotourism, which is defined as a support system to the tourists by sending out specific information in purpose of communicating the features of the geopark and accomplishing its service and education functions (Yan, 2010). In this sense, interpretation system is a communication activity. Traditionally, geoheritage interpretation is thought to consist of websites, traffic signs, mandatory instruction signs, location signs, direction signs, geosite interpretative panels, maps, geopark logo and/or, brochures, leaflets that convey information of an area. Therefore, a lot of recent studies focused on the improvement of the interpretation panel system in a geopark (e.g. Tubb, 2003; Kejian \& Lei, 2010; Moreira, 2012).

Although there are differences in traditions, civilizations, and management systems among countries, the effective geoscience communication is a shared value. The conservation of geological sites emerged in China in the $1980 \mathrm{~s}$, which has continued ever since in accordance with national laws and regulations (Pan, 1995; Yang, et al., 2011). China has established 29 global geoparks amongst the total 102 global geoparks worldwide and 171 national geoparks as of May, 2013. The fast-growing geopark network in China has given rise to both experience and lessons. Compared to the National Park System of the United States, Chinese geoparks lag behind in the conversion of geosciences knowledge for the purpose of geotourism. Learning from the achiecments of U.S. national parkscan be beneficial for the common value of effectiveness communication of geosciences.

In the present paper, an attempt has been made to explore an interpretation system model for geoparks, by reviewing the lessons and experiences from Longhushan and Taining global geoparks in China and Zion National Park in the United States.

\section{Geopark Development in China}

\section{Introduction to Chinese geoparks}

Geotourism in China has grown significantly thanks to the addition of many geoparks. Geotourism improves economic engine linked to the specialties of each Geopark (e.g. Ting \& Xun, 2004; Farsani, et al., 2011). Most geoparks in China developed from existing national parks and national scenic areas. Table 1 shows that it is popular to designate a geopark with a mixture of different titles. A geopark administrative committee is often in charge of management of other types of properties. For example, LonghushanGuifeng Global Geopark (will use Longhushan Geopark in short) and Taining Global 
Geopark (Taining Geopark in short), were designated National Scenic Areas, Global Geoparks, World Natural Heritage Sites, National Scenic Areas and National 5A-rated Tourist Attractions. Each property needs to follow its specific criteria to construct and is managed by different departments of the Chinese central government, which can lead to problems in the construction of a geopark. This is to be discussed in the section Problems exist in the development of Chinese geoparks.

Table 1 Chinese superior administration department to different designations

\begin{tabular}{|l|l|l|l|}
\hline $\begin{array}{l}\text { National superior } \\
\text { administrative } \\
\text { department }\end{array}$ & Title designation & Initiation time & Number \\
\hline $\begin{array}{l}\text { China National } \\
\text { Tourism Administration }\end{array}$ & $\begin{array}{l}\text { National 5A-rated } \\
\text { tourist attractions }\end{array}$ & $\begin{array}{l}\text { The rating system } \\
\text { was started in 2002 } \\
\text { (The AAAA-rating } \\
\text { was initiated in the } \\
\text { evaluation system in } \\
2007)\end{array}$ & $\begin{array}{l}162 \text { National 5A-rated } \\
\text { Attractions as of 2013 }\end{array}$ \\
\hline $\begin{array}{l}\text { Ministry of Housing } \\
\text { and Urban-Rural } \\
\text { Development of P.R. } \\
\text { China }\end{array}$ & National Scenic Area & 1982 & $\begin{array}{l}\text { 225 National Scenic } \\
\text { Areas as of 2012 }\end{array}$ \\
\cline { 2 - 4 } $\begin{array}{l}\text { UNESCO World } \\
\text { Heritage }\end{array}$ & 1987 & $\begin{array}{l}45 \text { UNESCO World } \\
\text { Heritage Sites as of } \\
2012\end{array}$ \\
\hline $\begin{array}{l}\text { Ministry of Land and } \\
\text { Resources of P. R. } \\
\text { China }\end{array}$ & National Geopark & 2000 & $\begin{array}{l}219 \text { National Geoparks } \\
\text { as of 2013 }\end{array}$ \\
\cline { 2 - 4 } & $\begin{array}{l}\text { UNESCO Global } \\
\text { Geopark }\end{array}$ & 2004 & $\begin{array}{l}29 \text { Global Geoparks as } \\
\text { of 2013 }\end{array}$ \\
\hline
\end{tabular}

Source: authors

\section{Interpretation system of geoparks in China: A close look at Longhushan Geopark and Taining Geopark}

Taining and Longhushan geoparks are chosen as case studiesto introduce the interpretation system of Chinese geoparks. Longhushan Global Geopark joined in the Global Geopark Network (GGN) in 2007 and Taining Global Geopark was founded in 2005. They are two of successful examples from the Chinese Geopark Network. Longhushan Geopark and Taining Geopark are located in southeast China (Figure 1). They are characterized by danxia (literally means red-colored beds in Chinese) landform and rich in cultural relics. Danxia landform is featured by steep cliffs, with caves as a secondary character (Figure 2a and Figure 8). Like other Chinese geoparks, Longhushan and Taining were established in accordance with the Operating Instructions for Establishment of Chinese National Parks (GEDMLR, 2006) and the guidelines of UNSCO (GGN, 2010). A Chinese geopark interpretation system, as required, comprises of the following items: 
(1) Geopark steles (including a mater stele and a secondary stele);

(2) A geological museum (no smaller than $800 \mathrm{~m} 2$ );

(3) A cinema for the geosciences education film;

(4) Geosite interpretive panels (no less than 50);

(5) Location signs and direction signs (no less than 3);

(6) Geotourism guide maps.

Figure 1 Locations of Longhushan Geopark and Taining Geopark in China, as marked by black triangles. LHS: Longhushan Geopark; TN: Taining Geopark. Polygons refer to the administrative provinces of China

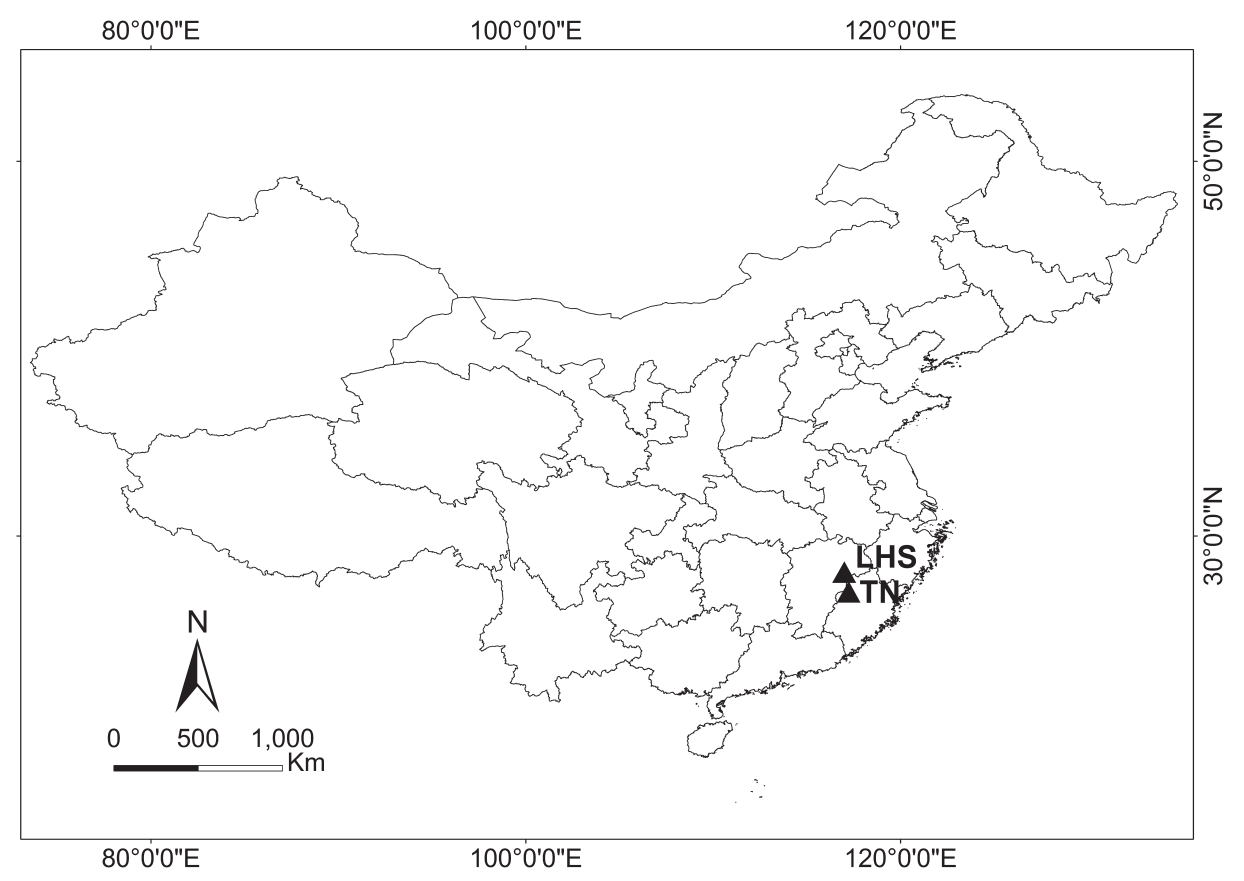

Source: authors

Besides the basic fulfillment of constructions, these two geoparks have developed their successful experiences.

\section{Longhushan Global Geopark}

Longhushan Geopark is featured by a variety of danxia landforms developed from the Cretaceous red beds covering $997 \mathrm{~km}^{2}$ (Figure 2a). The park exhibits many isolated peaks, hoodoo peaks, steep cliffs, collapse structures, and landforms. Besides its abundant geoheritage, Longhushan is also known as its fruitful cultural relics. In Longhu- 
shan and Taining geoparks, geological museums, interpretation panels, cinemas, visitor centers, and other supporting infrastructures have been established (Figure 2b, Figure 3 and Figure 9).

Figure 2 (a) An example of danxia landform from Longhushan Geopark; (b) The Longhushan Geological Museum

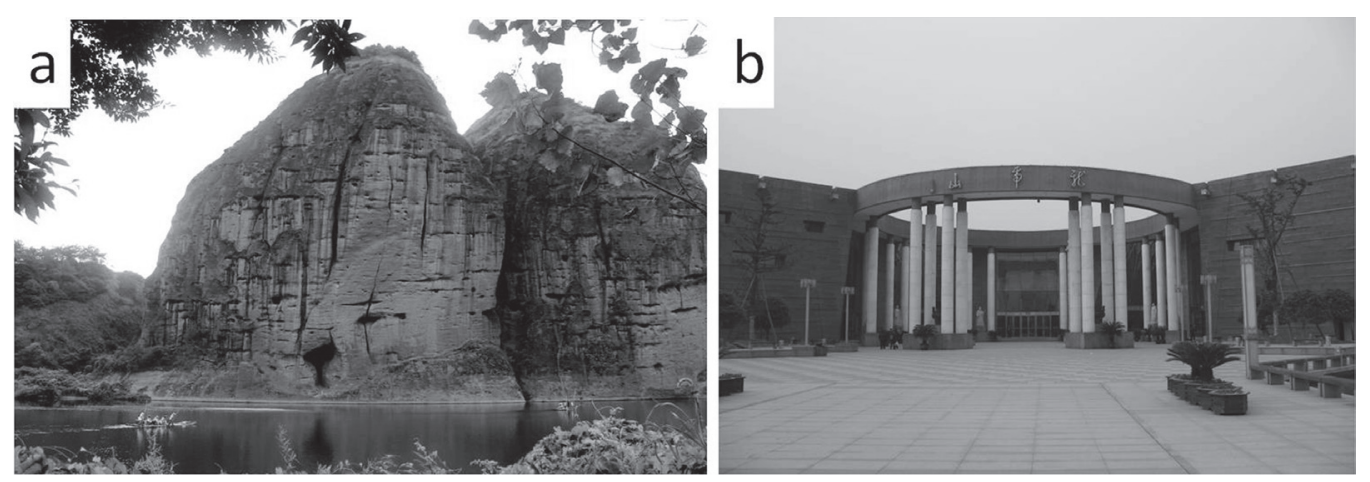

Photo: Ren, Simonson and Pan (2013)

Figure 3 Interpretive panels in Longhushan Geopark
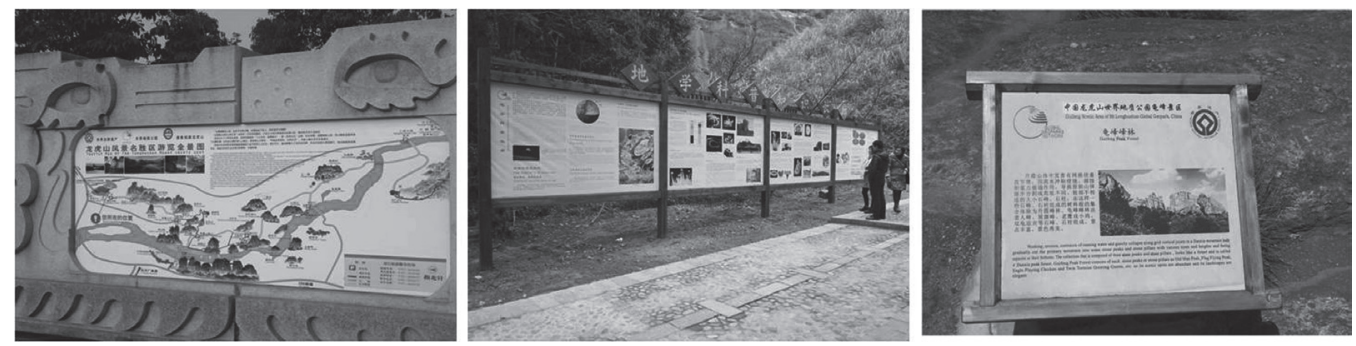

Photo: Ren, Simonson and Pan (2013)

Successful combination of culture with geoheritage in Longhushan Geopark can be found in the adding geosciences interpretation into the existing cultural activities and physical cultural structures. Longhushan is the birthplace of Taoism, which is the only indigenous Chinese religion. It has 25 million followers worldwide with a history of more than 1900 years. Taoism has great influence on Chinese traditional culture such as life style and thinking methods. Taoism emphasizes living in harmony with the Tao ("path" or "principle"). Zhang Daoling, the founder of Taoism, preached the philosophy of Taoism by interpreting balance of nature in Longhushan (Ren, 2012). The goal of the Taoists is to attain harmony with the Tao and live in accord with nature. Consequently, the Taoism doctrine of harmonious development with nature happens to be the same as the sustainable development philosophy of geoparks, which is a delicate combination under the geopark framework. This religion and the derived Chinese ancient philosophy become a good way to help tourists' recognition of the value of Longhushan as a geo- 
park. Taoist temples in Longhushan are developed into culturally significant geosites, as also in the cases of the archeological site of the Nanyan Temple and the calligraphy inscriptions on cliff surfaces that are hundreds of years old (Figure 4).

Figure 4 Culturally significant geosites in Longhushan Geopark. (a) Nanyan Temple constructed in a big arched cave (Tang Dynasty 827-835); (b) Calligraphy inscriptions on cliff surfaces (Tang Dynasty 827-835)
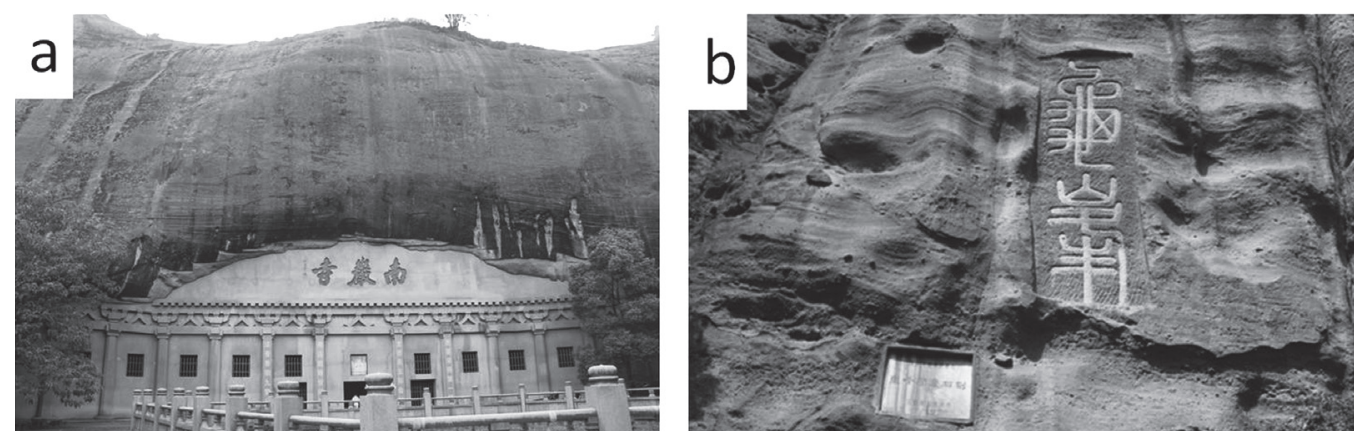

Photo: Ren, Simonson and Pan (2013)

There is a positive feedback from Longhushan Geopark tourists, which concerns the innovation of the food specialty service to the Taoism culture attraction. The "Ba Gua Feast" is the popular signature food combo made of delicious local products (Figure 5). The Ba Gua (literally "eight symbols" in Chinese) denotes eight diagrams used in Taoist cosmology to represent the fundamental principles of reality. These eight diagrams symbolize the eight natural phenomena: sky, earth, thunder, wind, water, fire, mountain and lake. Eight diagrams are Chinese's earliest knowledge of the universe, which contained

Figure 5 (a) Ba gua (eight symbols) feast; (b) The Eight Trigrams used in Taoist cosmology (see text in details)
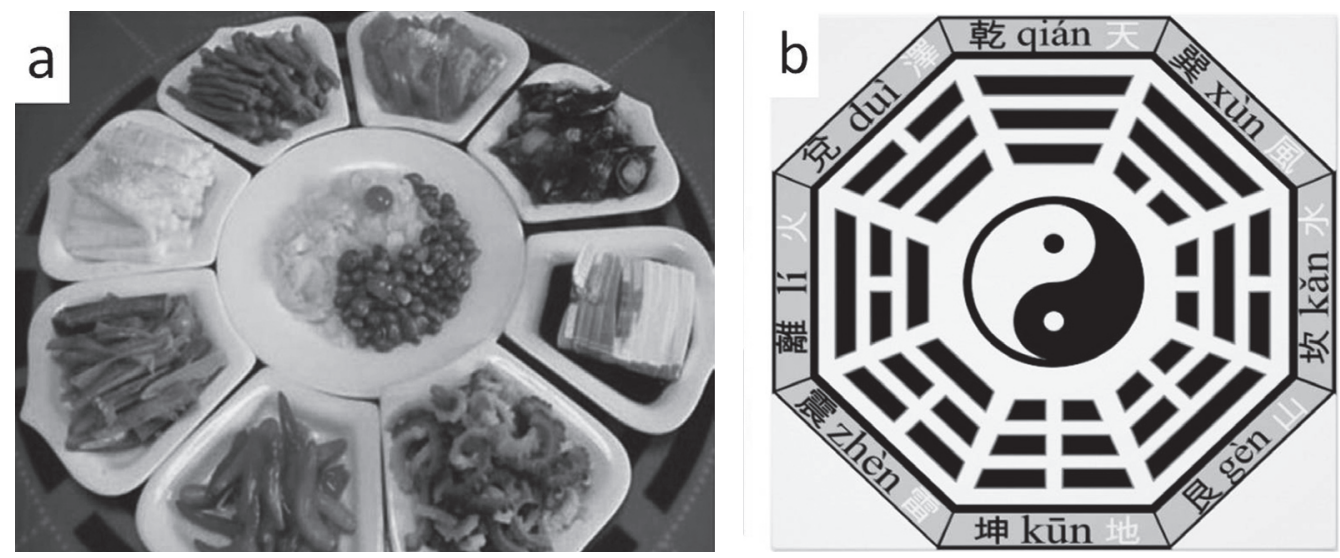

Photo: Ren, Simonson and Pan (2013) 
a simple dialectical materialist point of view. When the Bagua concept is presented by food, it becomes more interesting than just being read from interpretive panels. Tourists enjoy the culinary experience and easily connect their experience with geosites they visited in the geopark.

Local residents are highly encouraged to participate in the geotourism and are offered free training courses or employment opportunities. Most of the local dwellers are working for the geopark. There is a small private business named "the floating bamboo market", setting up on single bamboo rafts, run by local people (Figure 6a). Those floating rafts, paddling in the river, offer local food and snacks for tourists as they take a bamboo-rafting tour along a transparent meander in the geopark. Bamboo-rafting is a restful tour with beautiful views of surrounding of danxia landscape (Figure 6b). It is an interesting experience for tourists to enjoy geosites and local customs.

Figure 6 (a) The bamboo floating market in Longhushan Geopark; (b) Bamboo-rafting in Long-
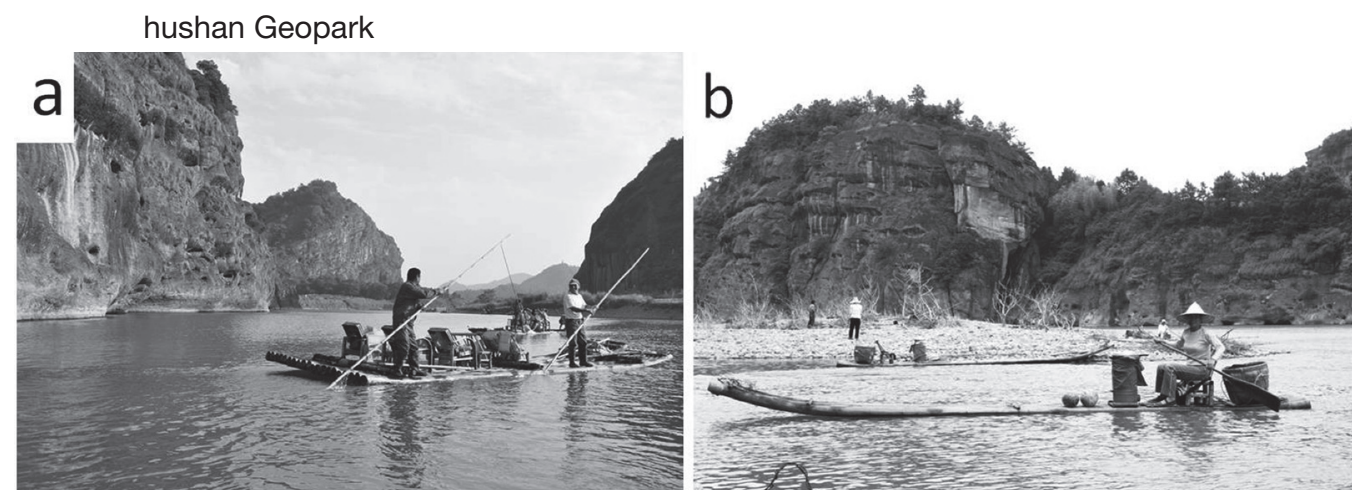

Photo: Ren, Simonson and Pan (2013)

Carved into the cliff walls along the river, caves with various shapes formed by differential weathering and erosion can be seen. Inside some big caves in vertical face of cliffs, there are more than 200 cliff tombs with a history of 2600 years. Those are the world-famous archeological sites known as the Hanging Coffins. The ancient funeral custom was very popular in Asian history. People believed that the hanging coffins could prevent bodies from being taken by beasts and also bless the soul eternally. It is still a mystery how those coffins were put into the caves without any help of modern lifting machines. Based on the preliminary research by a Chinese university, Longhushan Geopark provides a performance for tourists to reflect on this scenario at the geosite (Figure 7a). As they watch the show, tourists easily follow this culture exploration as well as the interpretation on how those big caves formed from geological processes. This has been a very successful utilization of culture and geology.

The other example is the cormorant fishing performance. The local fishers used to catch fish with the assistance of cormorants. In order to protect the ecosystem of the park, they no longer live on fishing. They are employed by the geopark and demonstrate cormorant fishing show for tourists (Figure 7b). Those cultural activities dramatically 
increase tourists' curiosity to pursue the natural processes that formed large caves and rivers. The linkage between geotousim activities and Earth science education affords a context-based Information delivery platform. This inspiration from the input of geointerpretation has recently caught researchers' attention (Barron, et al., 2011; Gordon, 2012).

Figure 7 (a) Hanging coffins performance site in Longhushan Geopark (Arrow pointing to the cliff tomb where coffin is to be put in.); (b) Cormorant fishing performance in Longhushan Geopark
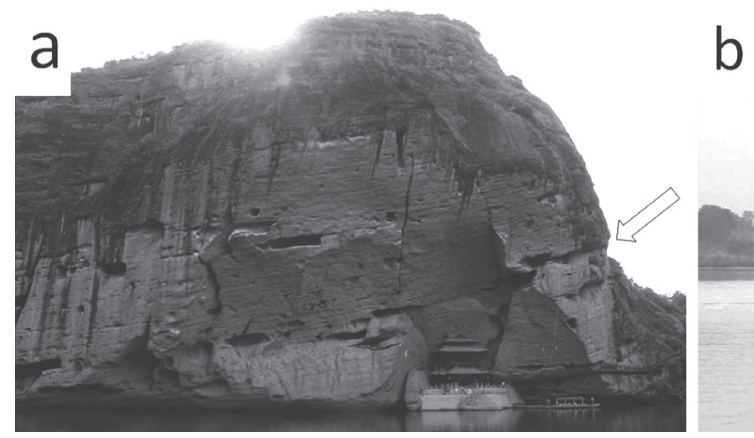

Photo: Ren, Simonson and Pan (2013)

\section{Taining Global Geopark}

Taining Global Geopark is located in Southeast China with an area of $492.50 \mathrm{~km}^{2}$. It is characterized by a variety of danxia landform, granite landforms, and tectonic landform. It demonstrates a strong ecological environment and rich historical sites. Danxia landforms have graceful shapes, such as red cliffs, deep-incised valleys, and tower peaks (Figure 8). The geopark boasts a variety of caves and caverns. Thus, it has a reputation as a "cave museum". Interpretive panels in the geopark are using natural materials such as wood and rock to blend harmoniously with the environment (Figure 9).

Ganlu Temple has been standing unexpectedly in a big danxia arched cave and it has been for about 850 years. Its construction is considered an architectural wonder featured by a unique single-pillar supporting the foundation for the whole buildings. The temple complex is more than $80 \mathrm{~m}$ high, $30 \mathrm{~m}$ deep, and $30 \mathrm{~m}$ wide at the superstructure, while only $10 \mathrm{~m}$ wide at the bottom which makes it like a flipped triangle from the distance. Ancient Asian architectural design philosophy emphasized creating a harmonious environment by bonding both man-made and natural materials through placement. The temple has been a national scenic spot since before the establishment of the geopark. It is now opened to tourists as a culturally significance geosite. The temple is an appropriate site to introduce the surface processes that sculptured the caves. 
Figure 8 A distant view of danxia landform in Tainning Geopark

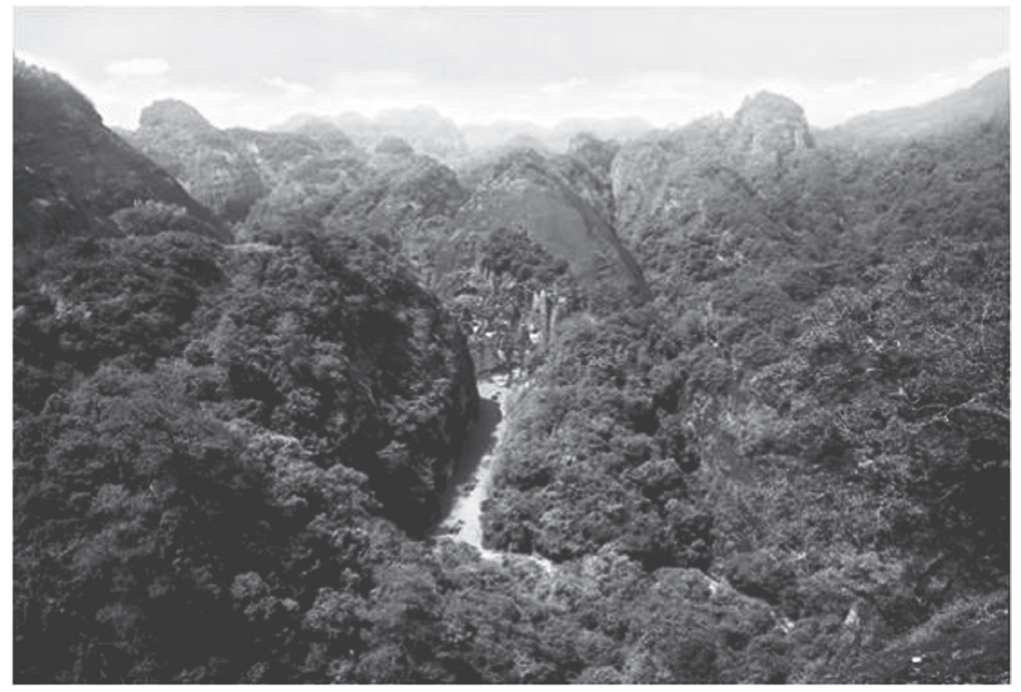

Photo: Ren, Simonson and Pan (2013)

Figure 9 Interpretation panels in Taining Geopark
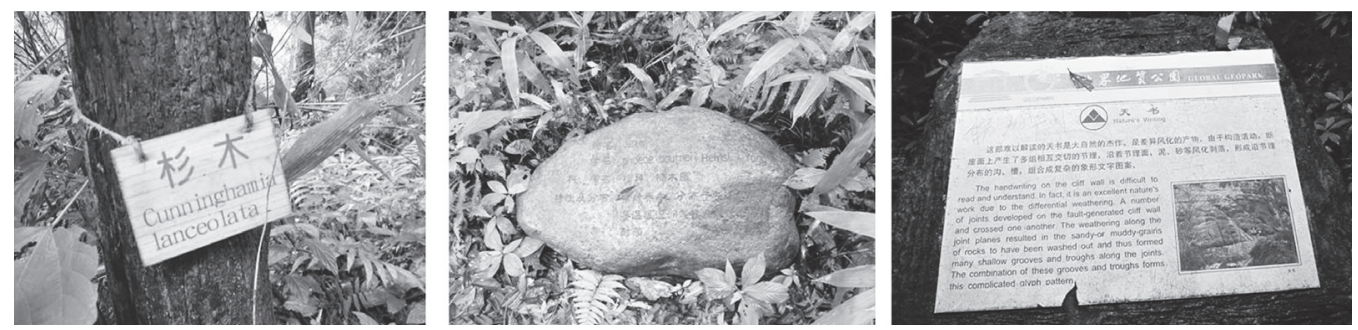

Photo: Ren, Simonson and Pan (2013)

It seems that serendipitous learning of geosciences is more efficient for tourists when it can be related to other information or experiences surrounding the geotourism, for example, being merged with culture attractions. With a few dramatic exceptions, the natural features in the geoparks have not changed appreciably, but explanations of how the landscapes developed have undergone many changes with geoscience input. The evolution of people's recognitions of their natural environment as well as the derived civilizations and customs are interesting topics for tourists. After all, education from geoparks should not be didactic. Geopark, using a holistic approach, can bring a new aspect for integration of the tangible and intangible values of a geopark. However, the mutual relevancy of the different elements does not spontaneously generate in geotourism. Support from a scientifically designed interpretation system is a necessity. Sound interpretive planning provides an organized method for a geopark's establishment of interpretive and educational programs. 
Figure 10 Ganlu Temple is built inside an arched danxia cave with single pillar supporting the whole building complex

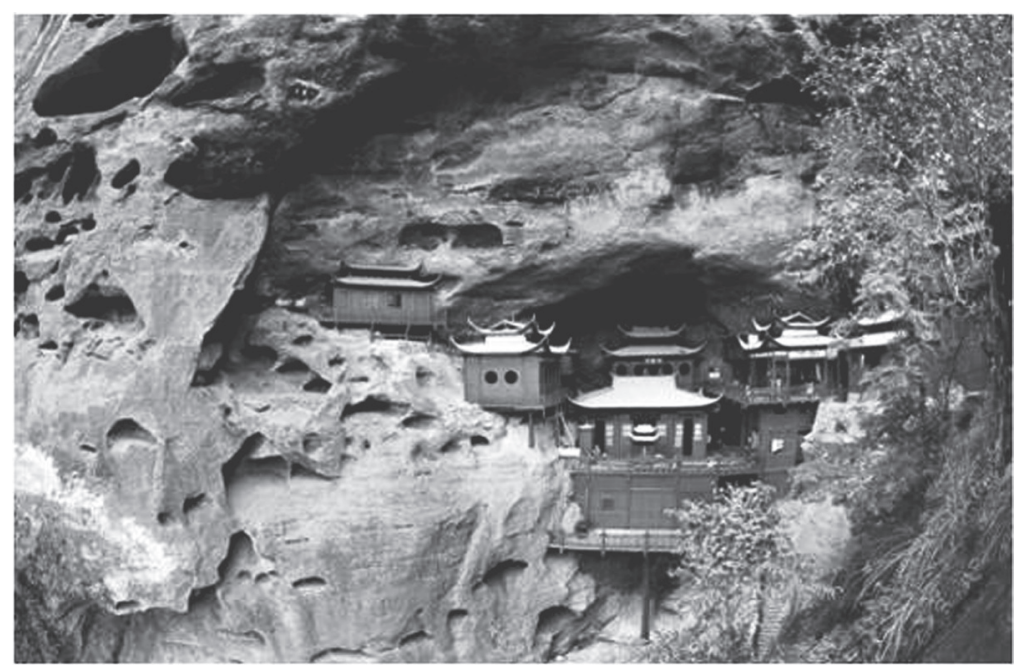

Photo: Ren, Simonson and Pan (2013)

\section{Problems exist in the development of Chinese geoparks}

The problems that arise of Chinese geoparks are mainly from miscommunication or inefficient geopark interpretation system (Lin, 2008; Yan, 2010; Yang \& Fu, 2011). In 2012, three Chinese geoparks received "yellow card" warnings from UNESCO despite their increasing economic achievements. The parks were criticized for inadequately disseminating knowledge of Earth sciences to the general public. In China, administratively, a geopark administrative committee very often takes charge of other mixed designations (Table 1). Therefore, confusion from geopark managers may stem from multi-criteria and various development philosophies practiced by different management departments. In many cases, when it comes to geopark development, managers are concerned much with the passage of objects from the physical constructions of trails, hotels, information panels at geosites, geological museums and exhibitions as well as commercial displays. All of these cannot fail or tourism promotion suffers. However, providing effective means for geoscience education and broader environmental issues to the public is a must for a geopark to be qualified in UNESCO's network.

Lessons are also learned from miscommunication of geoscience jargon, which is sometimes too professional for general tourists and therefore is less interesting and does not engage them. The design of geoparks is normally carried out by geological surveys (provincial or local level) or by geoscience departments of universities. There is still a lack of the experience necessary to encode academic science language into layman terms. Based on barriers to effective communication(Quill, 1995), It is suggested that five reasons why 
geoscience terminology information is difficult to understand by common tourists: (1) complexity of information presentation; (2) the use of unfamiliar scientific jargon; (3) difficulties in portraying geological processes which mostly take millions of years; and (4) difficulty that people of all literacy levels have in understanding information; (5) lack of attention, interest, distractions, or irrelevance to the receiver.

Another problem is from the dissatisfaction of the monotonous souvenirs. Tourists only find the same trinkets at any geopark in China (Zhang, 2008). The function of souvenirs has been noticed, as part of the geotourism, a useful tool in promoting a tourist destination's image (Thirumaran \& Thirumaran, 2013). The word "souvenir" means "to remember." People like to be reminded of special moments and events, and a souvenir serves as such a reminder.

\section{National Park System in the United States}

\section{Introduction to National Park System of the United States}

U.S. national parks are perhaps most notable for the way that they have adapted to broader economic, social, cultural, and political demands to become an enduring feature of U.S. culture while at the same time becoming keystones of biological diversity conservation (Schelhas, 2011). National Park System (NPS) of the United States is called "America's Best Idea." Since the founding of the first national park in 1872, the U. S. National Park System has existed with the purpose to conserve history and protect the vast landscapes and abound diversity of life found through the nation for the benefit of all future generation of Americans. The system includes more than 450 natural, historical, recreational, and cultural areas throughout the United States, its territories, and island possessions - more than 84 million acres in total as of 2012. The National Park system is administered by the National Park Service including not only the most extraordinary and spectacular scenic exhibition in the United States, but also a large number of sites distinguished for their historic or prehistoric importance, scientific interest, or superior recreational assets. The NPS provides technical assistance to its partners like State, tribal, and local governments, federal agencies, private organizations, and universities to promote the protection and preservation of cultural resources.

The National Park Services budget is divided into two primary areas, discretionary and mandatory spending. Within each of these areas, there are numerous specific purposes to which Congress directs the services activities (NPS, 2005). The budget of the National Park Service includes discretionary spending, which is broken out into two portions: the direct operations of the National Parks and the special initiatives. According to the Department of the Interior of the United States (2009), the service has been charged with five initiatives for Fiscal Year 2010. They include: Stewardship and Education; Professional Excellence; Youth Programs; Climate Impacts; and Budget Restructure and Realignment. 


\section{Zion National Park System and its interpretation system}

We choose Zion National Park as an example because it is also featured by enormous geoheritage sites. Case study allows us to refer to their effective communication as a success story to learn from. Designated in 1919, Zion National Park, with nearly 150,000 acres of protected area, is known for its incredible canyons and spectacular views. The canyon walls are covered with blind arches and alcoves, hanging valleys, and colourful surface stains (Figure 11).

Figure 11 (a) Location of Zion National Park in the United States (black triangle). Polygons are the states of the U.S.; (b) A landscape view of Zion National Park
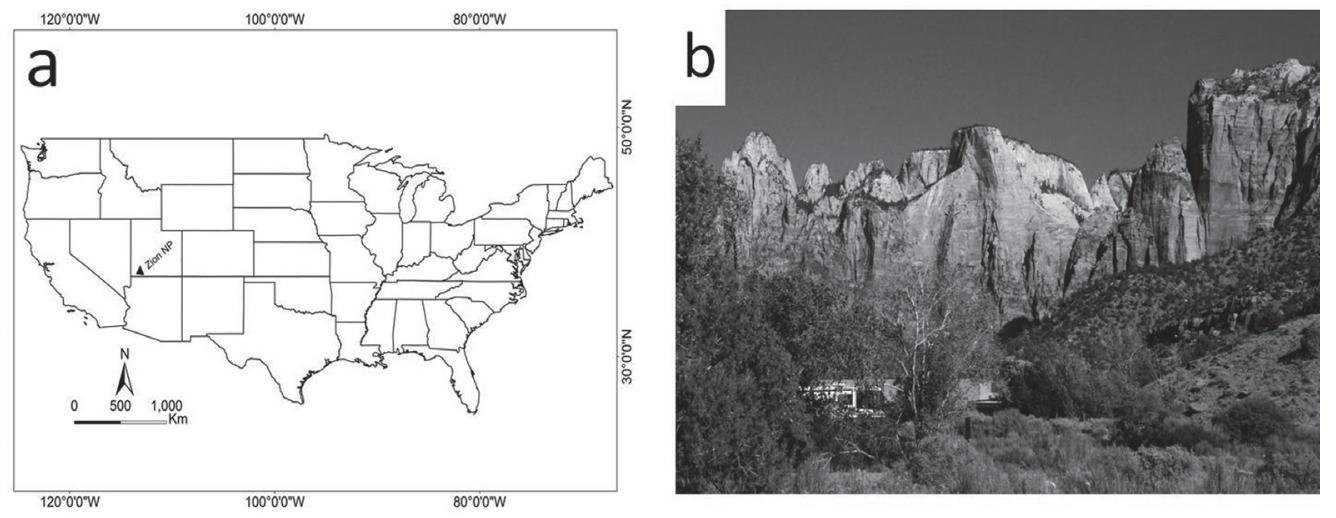

Source: authors

Tourists can learn information about Zion National park through websites, on-site interpretive panels, visitor centre, ranger programs, junior ranger programs, history Museum, and brochures, self-selected programs. Information about things to-do in the park is provided through diverse channels (e.g. Figure 12, Figure 13b and Figure 14). There are a lot outdoor activities such as horseback rides, biking and many others to meet the interests of the different tourist groups. The visitor centre offers a wide variety of information and services. Rangers give outdoor talks. Nearby there are displays with maps and attractions, showcasing many of the adventures to do both inside the park and beyond. Rangers are available to answer questions about Zion and hand outback country which are needed for all overnight hikes and technical slot canyons, within the park boundaries. Information about trail conditions, roads and weather forecasts are also available there as well as in the broachers and maps provided to tourists. Visitor can select their tours based on the information provided. Shuttle bus, self-guided trails and onsite interpretation panels are set up for tourism use (Figure 13). 
Figure 12 Things-To-Do inside Zion National Park and Things-To-Do nearby Zion National Park (Pictographs follow National Park Service standard)

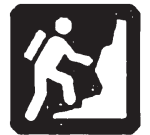

Backcountry

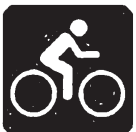

Biking

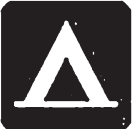

Camping

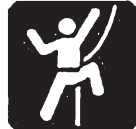

Canyoneering

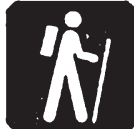

Hiking

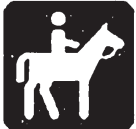

Horseback

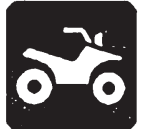

Offroad

Source: http://www.utah.com/nationalparks/zion.htm

Figure 13 (a) Shuttle bus service provided in Zion National Park; (b) On-site interpretive panel
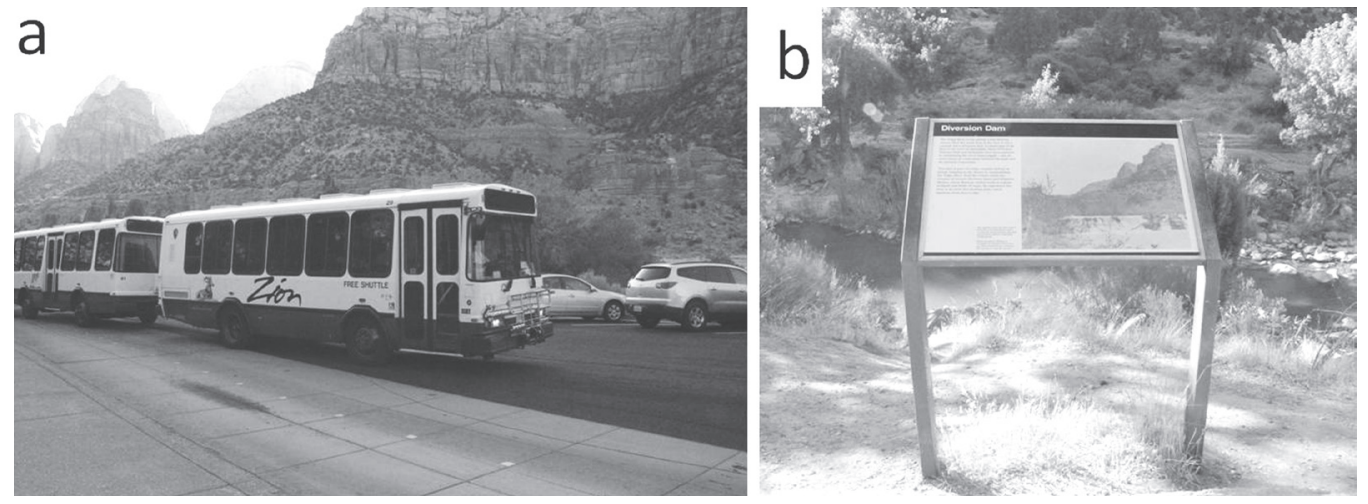

Photo: Ren, Simonson and Pan (2013)

A stewardship message of environmental conservation whispers to tourists in a management method. For the purpose of raising environmental protection awareness of the public and reducing plastic waste, bottled water is not for sale in Zion National Park except recyclable cups. There are several water refill stations in the park for tourists (Figure 14a).

Zion National Park has some of the best ranger programs; ranger/naturalist programs include guided walks, evening programs and talks (Figure 14b). Activity schedules are posted at the visitor centre and throughout the park. As in other National Parks in the United States, Zion has a Junior Ranger program. This is for children 6 to 12 years of age, and is held in the Zion Nature Centre. The Junior Ranger Program really helps the youth get the most out of their visit to a National Park and to become involved as an official Junior Ranger. 
Figure 14 (a) The water refilling station; (b) A picture of a ranger program in Zion National Park
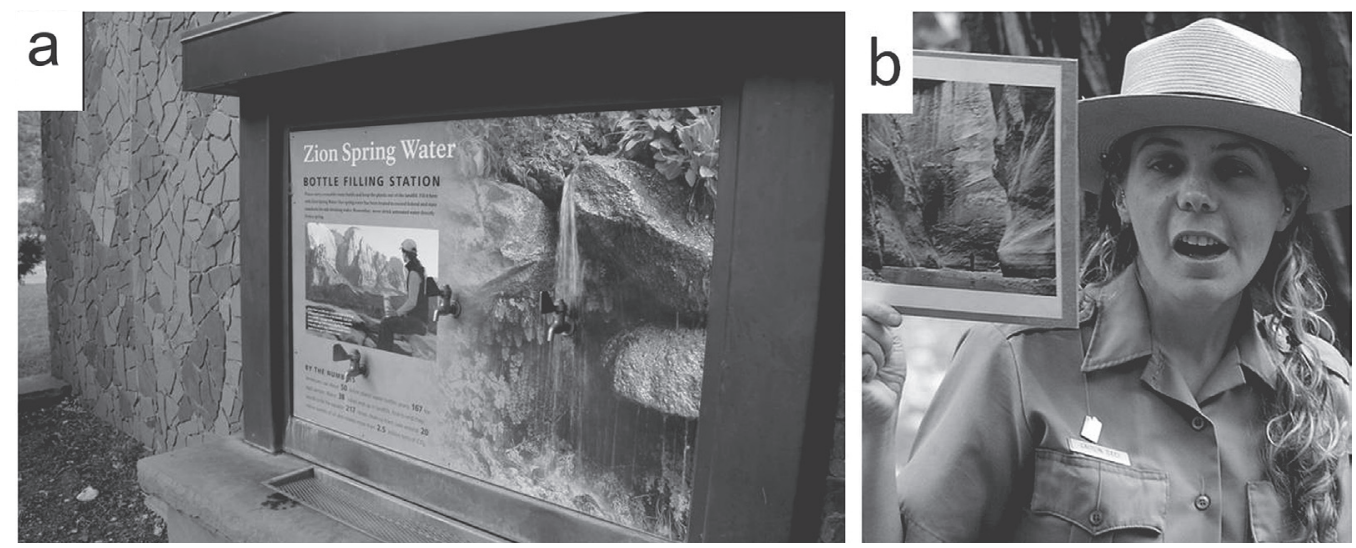

Photo: Ren, Simonson and Pan (2013); http://www.flickr.com/photos/35592860@N08/5212853850/

The U.S. National Park is very effective in invention of souvenirs products. At gift shops tourists can buy postcards, T-shirts, books, and much more that are directly related to the park that you are at. This gives people an opportunity to educate themselves and get a souvenir that is very specific and proof the visit at somewhere very specific as a complementary to the on-site interpretation panels.

\section{Comparison of Chinese Geoparks and U.S. National Parks}

With different development principles, National Parks in the United States have been established to protect the natural environment or historical heritage from development, which are keystones of ecology and biological diversity conservation. Geoparks focus on geoheritage conservation, which encompass one or more sites of scientific importance, not only for geological reasons but also by virtue of its archaeological, ecological or cultural value. Geopark meets its goals in a threefold approach of conservation, education and geotourism: conservation of most significant geological features and sites, education of the visiting public and support of research, and promotion of geotourism to increase public interest in our geoheritage (GGN, 2010).

Chinese geoparks lag behind U.S. national parks but are developing rapidly. They both cherish sustainability as an integral part of their development and provide open spaces and healthy recreation places for people. Basic supporting infrastructure for tourism such as interpretive panels, trails, visitor centers, museums, accommodations, restaurants and souvenirs are provided for tourists. Chinese geoparks embrace some registered national parks and protected areas with unique geological and cultural heritages sites. A lot of existing cultural attractions are directly converted into culturally significance geosites with interpretation of the environment by earth science.

In the United States, National Park Service support administration and technical guidance for National Park constructions. All construction in Nation Parks must be ac- 
complished in accordance with applicable codes and accepted standards. Designers of National Parks need to consult with the National Park Service about prevailing codes that apply within the park. National Park Service supports the interpretation system establishment by providing interpretation directly, which supports the preservation mission. According to the Interpretive Development Program from NPS, interpretive planning describes and facilitates opportunities to meet visitor experience goals. It takes visitor experience goals as that subset of experiences the park most wants to facilitate. They are generally those experiences that lead to the visitors' better understanding and appreciation of park resources without significantly impacting those same resources. They include what visitors do, sense, feel, and learn such as behaviors, sensory experiences, emotions, and knowledge (NPS, 2009). In China, there is no technical standard of geoheritage interpretation to follow. As discussed in section 2.1, mixed administration is popular in a lot of geoparks. There is no solid standard or service support for establishment of effective interpretation system for geoparks. Many geoparks are facing the shortage of geological professionals (Chen, 2003).

\section{A Systematic Communication Model for Interpretation of Geoheritage in Geotourism}

From the above all review of the lessons and experiences of Chinese geoparks and U.S. National Parks, an integrated interpretation system for geoparks is developed from the perspective of communication (Figure 15 and Figure 16). Rather than focuses on

Figure $15 \mathrm{~A}$ simplified model of the communication process in geotourism (developed and based on the common communication model from Craig (1999) and information design theory from Redish (2000))

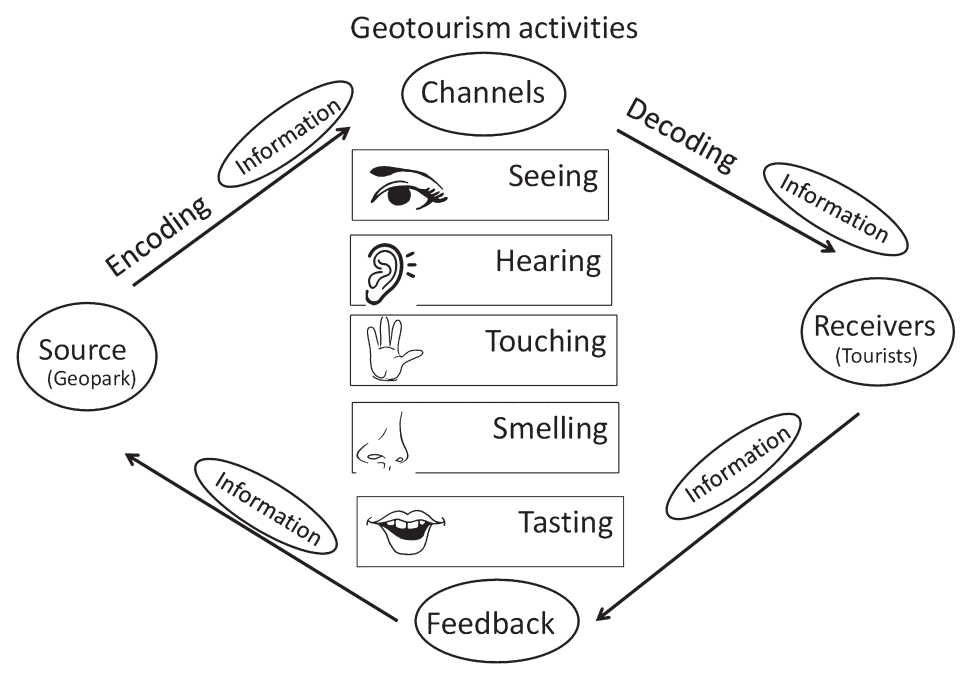

Source: authors 
interpretation panel system, this model considers geotourism per se as a dynamic interpretation communication system, including all activities and experiences that a visitor can experience. In the model, a geopark (source) delivers information about its unique cultural and natural values to target tourists (receivers) through tourism activities (channels). The activities consist of what visitors do, sense, feel, and learn such as behaviors, sensory experiences, emotions, and knowledge in a geopark. Geotourism is a system that comprises the geological elements of 'form and process' and the components of tourism such as attractions, accommodations, tours, activities, interpretation as well as planning and management (Dowling, 2011). Geotourism depends for its success upon identifying and promoting its physical basis (especially geosites). It is necessary to get advanced knowledge of resources of a geopark to help connect resource meanings with tourists' interests and points of view.

Communication is the process of sending and receiving messages or transferring information from one part (sender) to another (receiver) (Craig, 1999). In geotourism, this process includes the following phases (Figure 16):

Figure 16 A system model showing the communication process. Receivers' reaction levels are: Level 1-understanidng; Level 2-agreement; Level 3-attitude change; Level 4-Behavior change. See text in details

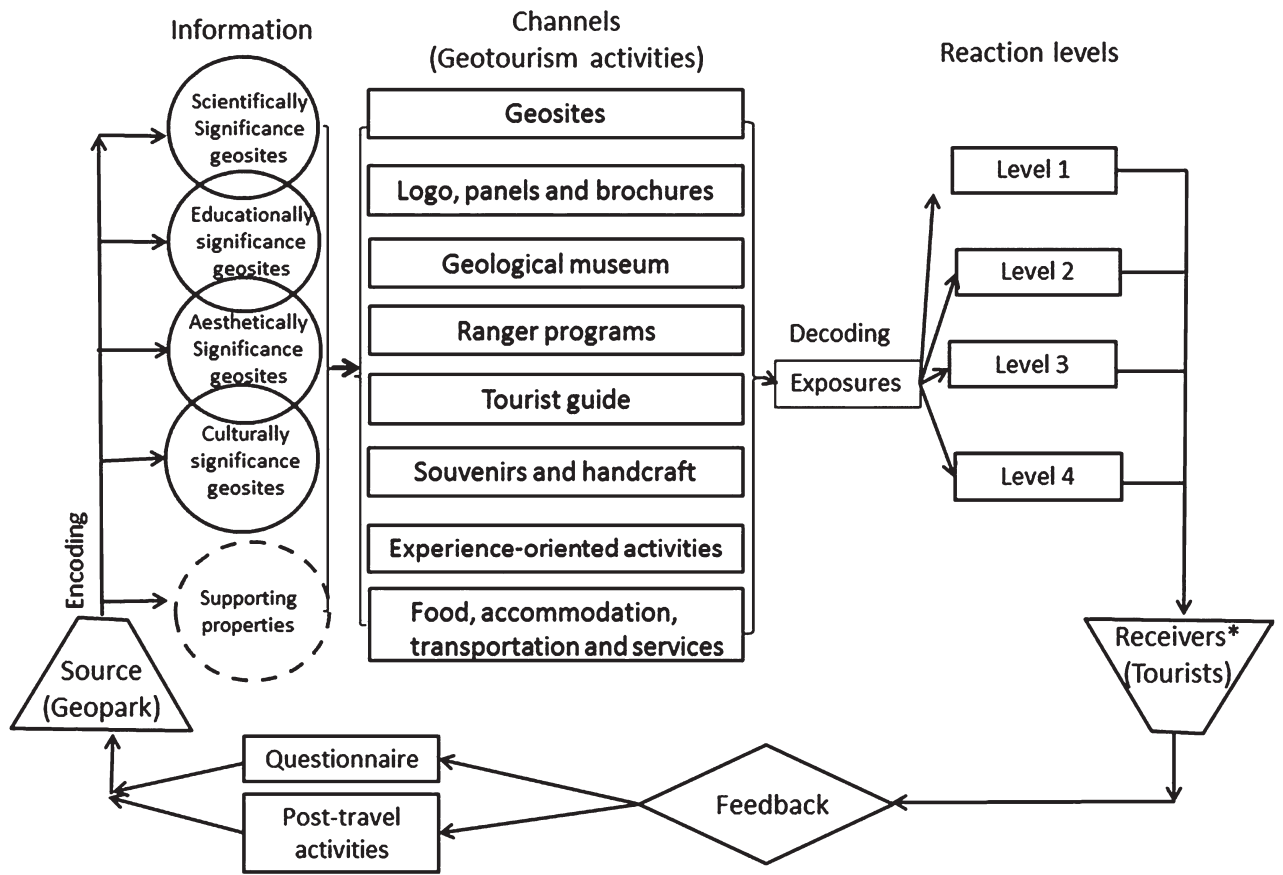

* At this point, receivers to have most fully decoded that which the geopark communicate to the receivers, through all experiences the tourists have got.

Source: authors 
The first step is examining the specific attributes that make a geopark unique and attractive to tourists. Inventories of existing cultural/ natural attractions and activities that the geopark contains must be prepared, including tangible and intangible properties. Attractions in the geopark may be divided into two main categories: core attractions (which always refer to the main natural and/or cultural features that are protected within it) and "supporting" attractions (which are of a secondary nature and include physical infrastructure and facilities) (Ceballos-Lascurain, 1996). Language used in preparing inventories should not be overly technical or scientific. According to the linkage with geoheritage, the attributes of the inventories can be classified into scientifically, educationally, culturally, aesthetically significant geoheritage sites. Those scientifically and educationally significant geoheritage sites include geologic features and landscapes in textbook, distinctive rock or mineral types, fossils, or other geological characteristics that are significant to education and research interest (Bailey \& Hill, 2010; GSA, 2011). Culturally significant geoheritage sites are places where geological features or landscapes play a role in cultural or historical events: or, sites where human-beings used to form a life style. In Longhushan Global Geopark, the "coffin lifting show" has proved to be a successful case in point. Aesthetically significant geoheritage sites include landscapes that are visually appealing because of their geologic features or processes. Only by documenting and assessing the values and attributes of the properties, can a geopark systematically communicate efficiently operate in the following steps. This step is to determine what message or information is worthy to communicate in a geopark.

The second step deals with the study of tourists' interests and backgrounds. Effective communication is through the sharing of common meanings between the sender and the receiver. By research of the potential tourist groups, a geopark may target these main tourist groups and provide them information that they are mostly interested in. According to Nowlan, et al. (2004), "at least three groups of people can be educated through parks". First, there are the politicians and or any other decision makers of the geoparks. For example, in the United States, National Parks organize geoscientists and politicians on field trips. Such trips provide an opportunity to cultivate productive relationships among parks, geoscientists, and decision-makers. The second group is the general public, which is the largest group of park visitors and yet perhaps the most difficult to educate. It is difficult to reach everyone in such a diverse group. The third group is children, as they are the hope of the future. Tourists have multiple perspectives on exposures to similar information. Some meanings are more relevant to some tourists than others.

The third step is to design and connect channels features (activities and experience provided in a geopark) to meet tourist' interests. It is the encoding process in the communication system, such as targeting items in the pre-created inventory and evaluating the appeal of the various attractions and activities for each targeted tourist group. Geopark designers need to choose suitable channels to achieve effective communication. Channel richness, which is the capacity of a communication channel to convey information effectively, should be evaluated (Johnson \& Lederer, 2005). One must follow by encoding these items into geotourism activities that can be sensed by tourists, making 
their intellectual and emotional connections to the meanings and significance inherent in the resource. This step should be conducted strategically, artistically, and effectively. One of the improvements can be obtained by meeting tourists' special needs. Alternative programs, or specially designed programs, provide a chance to improve the effectiveness of communication.

The fourth step is evaluating of communication activities through feedback and improving the interpretation system. In the communication process, feedback refers to a response from the receiver which gives the communicator an idea of how the message is being received and whether it needs to be modified (Richmond \& McCroskey, 1995). Effective interpretation approach will be improved by collecting feedback from tourists whether it is positive or negative.

According to communication theory, the impact of a communication expected from receivers (tourists) can be seen from: (1) Awareness/knowledge, impact can be assessed in terms of knowledge gains that can be traced by questionnaires or onsite questionanswer games;(2) Attitude/ perception, tourists are not only aware of the significance of the geoheritage, but, also, consciously protection of the environment. This level of outcome is normally hard to be traced; (3) Behavior, influence on people's daily life through long-term impact (Richmond and McCroskey, 1995). Tourists vary widely in backgrounds and they are intended to receive the information presented by a geopark based on their previous knowledge and experiences. Based on different levels of tourist reactions, we define them in our model as understanding, agreement, attitude change, and behaviour change from a superficial level to a more in-depth level (Figure 16). This information receiving process is accompanied by psychological activity. The basic question that could influence communication effectiveness is: are we providing the right communication means and products to the right people through the right channel (Westmyer, et al., 1998; Kao, 2013)?

Since a geopark interpretation system is dynamically interlinked through each communication stage, cooperation between different departments with individuals plays an important role in keeping the system in a geopark running well. As a centralized country, this should not be difficult for Chinese geoparks. For a less-centralized country, administration should enhance the internal communication among the various departments and cooperation. Interpretation is driven by a philosophy that charges interpreters to help audiences care about park resources so they might support the care for these precious resources.

There are various communication channels in the geotourism process, and they are not equally important in different civilizations or cultures. For example, in most of the Chinese geoparks, tourists are mainly from domestic areas and often travel in a group. Package tour and guided tours occupy the main geotourism market. Tourist guides play a leading role for a touring group. Interpersonal communication is a major communication channel. It is most important to improve their competences by providing them with training courses.

In the United Sates, independent tour or travel with family or in a small group is more popular. The long history of parks in North America has given rise to a tradition 
of family camping holidays that are part recreation and part education (Nowlan, et al., 2004). Sufficient information materials for self-guided instruction is crucial to reduce information uncertainty for tourists.

\section{Conclusions}

In this contribution, we present a new model of the integrated interpretation system for geotourism. In this model, geopark designers and managers are the information senders. The tourists are information receivers. All tangible and intangible resources contained in a geopark are carefully evaluated for geotourism purposes and integrated to channels from which tourists can receive information. Communication channels in geotourism include all mediums, facilities, services and activities which form an overall experience for tourists. Those channels are contextual with each other to explain significance and uniqueness of the geopark. The information in each channel can be obtained by tourists through their sensory systems of seeing, hearing, touching, smelling and/or testing. Communication effectiveness can be monitored by the feedback from tourists. This feedback is helpful for geopark managers to improve the encoding approaches in the future. The interpretation of geoheritage in a geopark is in the dynamic communication system. It is observed in the Longhushan and Taining geoparks that geoheritage interpretation is more effective when merged with local cultures. Handmade crafts and souvenirs are a useful tool in promoting a tourist destination's image. The physical presence of souvenirs helps locate, define and freeze in time a fleeting, transitory experience, and bring back into ordinary experience something of the quality of an extraordinary experience (Gordon, 1986; Hitchcock \& Teague, 2000). Suitably designed self-selected park ranger programs for target visitors are a good channel to engage tourists in communication and hence to improve the communication effectiveness of this integrated interpretation system.

Geotourism is on the rise worldwide. The increased interest in geological awareness, the phenomenal rise of the geopark, and the rising interest in geotourism as a tool for conservation of our geoheritage suggest the positive future for geotourism (Newsome \& Dowling, 2010). This paper provides a basis for geoparks to set up an integrated interpretation system of geoheritage for geotourism.

\section{Acknowledgements}

The authors acknowledge the stimulating discussions with Mr. Jock Whitworth during our stay in Zion National Park, and we would also like to thank Mr. Carl Wang. We are grateful to Dr. Martina Paskova. Her kind help initiated our work. Thanks also to the Administrations of Longhushan and Taining Global Geoparks for providing relevant documents. 


\section{Reference}

Bailey, H., \& Hill, W. (2010). The Future of North American Geoparks. The George Wright Forum, 27 (November 1), 52-59. Retrieved from http:// http://www.georgewright.org/271bailey.pdf.

Barron, et al. (2011). Geological input to a Landscape Character Assessment of the Cairngorms National Park (Open Report OR/10/003). Edinburgh, UK: British Geological Survey. Retrieved from http://nora.nerc.ac.uk/18481/1/OR10003.pdf.

Ceballos-Lascurain, H. (1996). Tourism, ecotourism, and protected areas: The state of nature-based tourism around the world and guidelines for its development. Gland, Switzerland: IUCN.

Chen, A. (2003). Some problems about the construction of National Geological park of China. Resources and Industries, 1, 58-64.

Craig, R. T. (1999). Communication theory as a field. Communication theory, 9(2), 119-161.

Department of the Interior of the United States. (2009). Budget Justification and Performance Information: Fiscal Year 2010: National Park Service. Retrieved from http:/ /www.nps.gov/aboutus/ upload/FY_2010_greenbook.pdf.

Dowling, R. K. (2011). Geotourism's global growth. Geoheritage, 3(1), 1-13. DOI: 10.1007/s12371010-0024-7.

Farsani, N. T., Coelho, C., \& Costa, C. (2011). Geotourism and geoparks as novel strategies for socio-economic development in rural areas. International Journal of Tourism Research, 13(1), 6881. DOI: $10.1002 /$ jtr.800.

GEDMLR (Geological Environment Department of the Ministry of Land and Resources). (2006). Operating Instructions for Establishment of Chinese National Parks. Geological Publishing House.

GGN (Global Geopark Network), UNESCO. (2010). Guidelines and Criteria for National Geoparks seeking UNESCO's assistance to join the Global Geoparks Network (GGN). Retrieved from http:// www.globalgeopark.org/portals/1/documents/2008ggn-guidelinesjuneendorsed.pdf.

Gordon, B. (1986). The souvenir: Messenger of the extraordinary. The Journal of Popular Culture, 20(3), 135-146. DOI: 10.1111/j.0022-3840.1986.2003_135.x.

Gordon, J. E. (2012). Rediscovering a sense of wonder: geoheritage, geotourism and cultural landscape experiences. Geoheritage, 4(1-2), 65-77. DOI: 10.1007/s12371-011-0051-z.

GSA (Gefological Society of America). (2011). Geoheritage: Position Statement draft. Retrieved from http://www.geosociety.org/positions.

Hitchcock, M., \& Teague, K. (2000). Souvenirs: the material culture of tourism. Aldershot/Burlington: Ashgate Publishing Ltd.

Johnson, A. M., \& Lederer, A. L. (2005). The effect of communication frequency and channel richness on the convergence between chief executive and chief information officers. Journal of Management Information Systems, 22(2), 227-252.

Kao, D. T. (2013). The impacts of goal orientation, terminology effect, and source credibility on communication effectiveness. Journal of Applied Social Psychology, 43(10), 2007-2016. DOI: $10.1111 /$ jasp.12154.

Kejian, X., \& Lei, L. (2010). Research on the designing of the interpretation panel of geoparks. In 2nd International Conference on Information Science and Engineering (ICISE) (pp. 1-4). IEEE.

Lin, M. T. (2008). Problems in Popular Science Function Display of Geoparks and countermeasures - With Taimushan State Geopark in Fujian Province as an Example. Scientific and Technological Management of Land and Resources, 3.

Newsome, D., \& Dowling, R. (2010). Setting an agenda for geotourism. In Newsome, D., \& Dowling, R. K. (Eds.). Geotourism: the tourism of geology and landscape. Oxford: Goodfellow Publishers Limited. 
Nowlan, G. S., et al. (2004). Protection of geological heritage: A North American perspective on Geoparks. Episodes-Newsmagazine of the International Union of Geological Sciences, 27(3), 172-176.

Nowlan, G. S., Bobrowsky, P., \& Clague, J. (2004). Protection of geological heritage: A North American perspective on Geoparks. Episodes-Newsmagazine of the International Union of Geological Sciences, 27(3), 172-176.

NPS (National Park Service), U.S. Department of the Interior. (2005). Government Printing Office, FY 2006 President's Budget, Executive Summary; Challenges. Tourism Planning \& Development, (ahead-of-print), 1-11.

NPS (National Park Service), U.S. Department of the Interior. (2009). Interpretive Development Program. Downloadable Documents. Retrieved from http://www.nps.gov/idp/interp/download.htm.

Pan, J. (1995). World culture and nature heritage of China. Beijing: Geological Publishing House (in Chinese).

Quill, T. E. (1995). Barriers to effective communication. In Lipkin, M., et al. (Eds.), The Medical Interview (pp. 110-121). New York: Springer. DOI: 10.1007/978-1-4612-2488-4_8.

Ren, F. (2012). The interplay between Taoist philosophy, Danxia Landscape and human beings 'Tao follows nature. In Migoń, P., \& Kasprzak, M. (Eds.), Proceedings of the $3^{\text {rd }}$ International Conference on Sandstone Landscapes (pp. 159-162). Wrocław, Poland: University of Wrocław.

Redish, J. C. (2000). What is information design? Technical Communication, 47(2), 163-166.

Richmond, V. P., \& McCroskey, J. C. (1995). Communication: Apprehension, avoidance, and effectiveness. Acottsdale, USA: Gorsuch Scarisbrick.

Schelhas, J. (2011). The US national parks in international perspective: The Yellowstone model or conservation syncretism?. In Polisciano, G., \& Farina, O. (Eds.), National Parks: Vegetation, Wildlife and Threats (pp. 83-103). Hauppauge, USA: Nova Science Publishers, Inc.

Thirumaran, K., Dam, M. X., \& Thirumaran, C. M. (2013). Integrating Souvenirs with Tourism Development: Vietnam's. Tourism Planning $\mathcal{E}$ Development, September. DOI: $10.1080 / 21568316.2013 .839471$.

Ting, Z., \& Xun, Z. (2004). Geoscientific significance and classification of National Geoparks of China. Acta Geologica Sinica English Edition, 78(3), 854-865. DOI: 10.1111/j.1755-6724.2004. tb00207.x.

Tubb, K. N. (2003). An evaluation of the effectiveness of interpretation within Dartmoor National Park in reaching the goals of sustainable tourism development. Journal of Sustainable Tourism, 11(6), 476-498. DOI: 10.1080/09669580308667217.

Westmyer, S. A., et al., (1998). Appropriateness and effectiveness of communication channels in competent interpersonal communication. Journal of communication, 48(3), 27-48. DOI: 10.1111/ j.1460-2466.1998.tb02758.x.

Yan, W. A. N. G. (2010). A Study on Tourism Interpretation System FORCOM of Geo-park. Journal of iuzhou Vocational E Technical College, 10(1), 19-24.

Yang, Q. J., \& Fu, H. L. (2011). The Evaluation of Interpretation System of Park from the National Geological Perspective of Tourists: Take the National Geological Park in Wulong as an Example. Journal of Chongqing Normal University (Natural Science), 11(3), 69-73.

Yang, G., et al. (2011). On the growth of national geoparks in China: Distribution, interpretation, and regional comparison. Episodes-Newsmagazine of the International Union of Geological Sciences, 34(3), 157.

Zhang, Y. (2008). Limiting factors for the Development of China's Tourism Shopping and Countermeasures. International Journal of Business and Management, 3(4), 127-131. 